$\begin{array}{lr}\text { Universitas } & \text { Vol. } 37 \\ \text { Núm. } 78\end{array}$

\title{
Type A Botulinum Toxin as Complement to Gingivoplasty in the Treatment of Gummy Smile. Case Report*
}

Toxina botulínica tipo A como complemento de la gingivoplastia para tratar sonrisa gingival. Descripción de un caso

Irineu Gregnanin Pedron ${ }^{\mathrm{a}}$

University of São Paulo, Brasil

Bottoxindent Institute, Brasil

igpedron@alumni.usp.br

ORCID: http://orcid.org/0000-0002-2677-5539
DOI: https://doi.org/10.11144/Javeriana.uo37-78.tabt Redalyc: http://www.redalyc.org/articulo.oa?

$\mathrm{id}=231262007007$

Date received: 08 January 2018

Date accepted: 04 June 2018

Date published: 18 June 2018

\section{Abstract:}

Background: The pursuit of esthetic excellence has become a major goal in the dental treatment. Gummy smile is one of the complaints of the patients, since such a situation can influence self-esteem and social relationships. The beauty of the smile is not only constituted by the shape, position and size of the teeth, but also based on the characteristics of the gingival tissue and conformation of the lips, which should be as harmonious as teeth. The development of new more conservative techniques may provide a better therapeutic option than surgical procedures, such as the application of botulinum toxin, in the treatment of gummy smile. Purpose: To present the case of a patient who presented dentogingival discrepancy caused by gingival overgrowth and gummy smile, treated by gingivoplasty and complemented by application of botulinum toxin. Description of the case: The gingivoplasty was performed followed by the application of botulinum toxin type A. Results: The gingivoplasty resulted of the improvement of gingival arches and the application of botulinum toxin promoted the dehiscence of upper lip, reducing the gingival exposure. Conclusions: The application of botulinum toxin, associated with gingivoplasty, is an important tool at the management of gummy smile, optimizing smile harmony and achieving improved self-esteem and quality of life.

Keywords: botulinum toxins type A, dental aesthetics, dentistry, gingival overgrowth, gingivoplasty, gummy smile, periodontics.

\section{Resumen:}

Antecedentes: La búsqueda de la perfección estética se ha transformado en un objetivo importante en el tratamiento odontológico. La sonrisa gingival es la queja más frecuente de los pacientes, ya que esta situación influye en la autoestima y en las relaciones sociales. La belleza de la sonrisa no está únicamente constituida por la forma, la posición y el tamaño de los dientes; la sonrisa también la constituyen las características del tejido gingival y la forma de los labios, los cuales deben tener una armonía, así como la tienen los dientes. El desarrollo de nuevas técnicas más conservadoras pueden ofrecer una opción terapéutica mejor que una cirugía, por ejemplo, la aplicación de toxina botulínica, en el tratamiento de la sonrisa gingival. Objetivo: Presentar el caso de una mujer que tenía discrepancia dentogingival ocasionada por el crecimiento exagerado de su encía y sonrisa gingival, tratada por gingivoplastia, y complementado por la aplicación de toxina botulínica. Descripción del caso: La gingivoplastia se realizó seguido de la aplicación de toxina botulínica tipo A. Resultados: La gingivoplastia resultó de la mejoría de los arcos gingivales y la aplicación de toxina botulínica promovió la dehiscencia del labio superior, reduciendo la exposición gingival. Conclusiones: La aplicación de toxina botulínica, asociada a la gingivoplastia, es una herramienta importante en el manejo de la sonrisa gingival, pues mejora la armonía de la sonrisa y se alcanza una mejor autoestima y calidad de vida para el paciente.

Palabras clave: estética dental, gingivoplastia, odontología, periodoncia, sobrecrecimiento gingival, sonrisa gingival, toxinas botulínicas tipo A.

\section{Author notes:}

\footnotetext{
${ }^{a}$ Corresponding author. E-mail: igpedron@alumni.usp.br
} 


\section{Introduction}

Currently, the demand for cosmetic procedures has grown exponentially. Dental procedures, as well as medical ones, besides working to obtain the principle of health promotion, seek smile esthetics, as the smile is a form of communication and socialization that expresses many feelings $(1,2,3)$.

Facial esthetic harmony correlates directly with the smile and this, in turn, is formed by the union of three components: teeth, gum and lips $(1,2,3,4)$. The smile becomes esthetically pleasing when these elements are disposed in suitable proportion, and exposure of the gingival tissue is limited to $3 \mathrm{~mm}$. When the gingival exposure is greater than $3 \mathrm{~mm}$, it is characterized the non-esthetic condition called gummy smile, which affects some patients psychologically $(1,2,5,6,7,8)$.

Several therapeutic modalities have been proposed for the correction of gummy smile, among them: gingivectomy or gingivoplasty $(2,3,5,6,7)$, myectomy $(6,8)$ and orthognathic surgery $(6,8,9)$; and the last two procedures are more invasive and associated with high morbidity (6). In contrast, the use of botulinum toxin can be considered as a therapeutic option to surgery, because it is a more conservative method, more effective, faster and safer, as compared to surgical procedures $(1,5,10)$.

Botulinum toxin is synthesized by Gram-positive anaerobic bacterium Clostridium botulinum (6,8,9), and inhibits the release of acetylcholine at the neuromuscular junction, preventing muscle contraction. There are seven distinct serotypes of toxins (A, B, C1, D, E, F, and G). However, the subtype A is the most frequently used clinically and the most powerful (6).

Currently, botulinum toxin has been shown effective in the treatment of gummy smile in patients with hyperfunction of the muscles involved in smiling, as well as in patients with other disorders such as temporomandibular disorders (hypertrophy of the masseter muscle, bruxism, clench) and myofascial pain $(1,6,9)$. The purpose of this study was to report a case of a patient who presented gingival overgrowth and gummy smile and was treated by application of botulinum toxin type A complementing the gingivoplasty.

\section{Description of the case}

A Caucasian female, 28 years old, attended the particular clinic complaining gummy smile. Clinically, the patient presented severe anatomic discrepancy between the length of the maxillary teeth (Figure 1), and prominent gingival display, with more than $4 \mathrm{~mm}$, featuring gummy smile. 


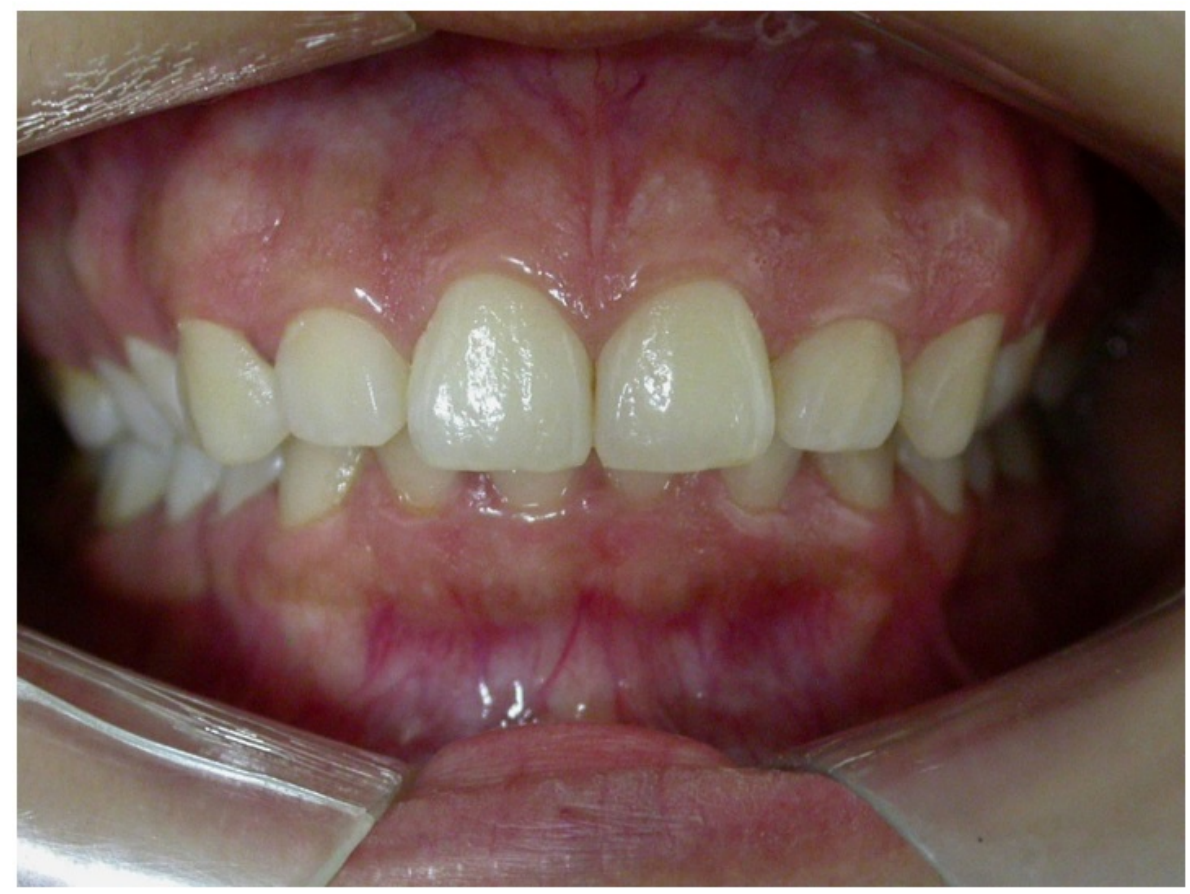

FIGURE 1

Initial clinic aspects presenting mild anatomical discrepancy

between the length of teeth $11,12,12,21,22$ and 23

Source: own elaboration.

The gingivoplasty was proposed. Before the surgical procedure, the patient was oriented about oral hygiene, in order to reduce gingival inflammation and prevent the possibility of recurrence of gingival overgrowth.

Under local infiltrative anesthesia, gingivoplasty was performed by determination of the bleeding points with the aid of a millimeter probe and the union of these points was made with the electric scalpel (2). The length of the teeth was increased, characterizing the new dental zenith. Posteriorly, the scraping was performed, resembling the technique of external bevel, with the purpose of enhancing tissue repair (Figure 2). There was no need for the use of surgical cement, given that the process of the wound occurs by secondary intention. The patient was counseled, and analgesics were administered postoperatively. 


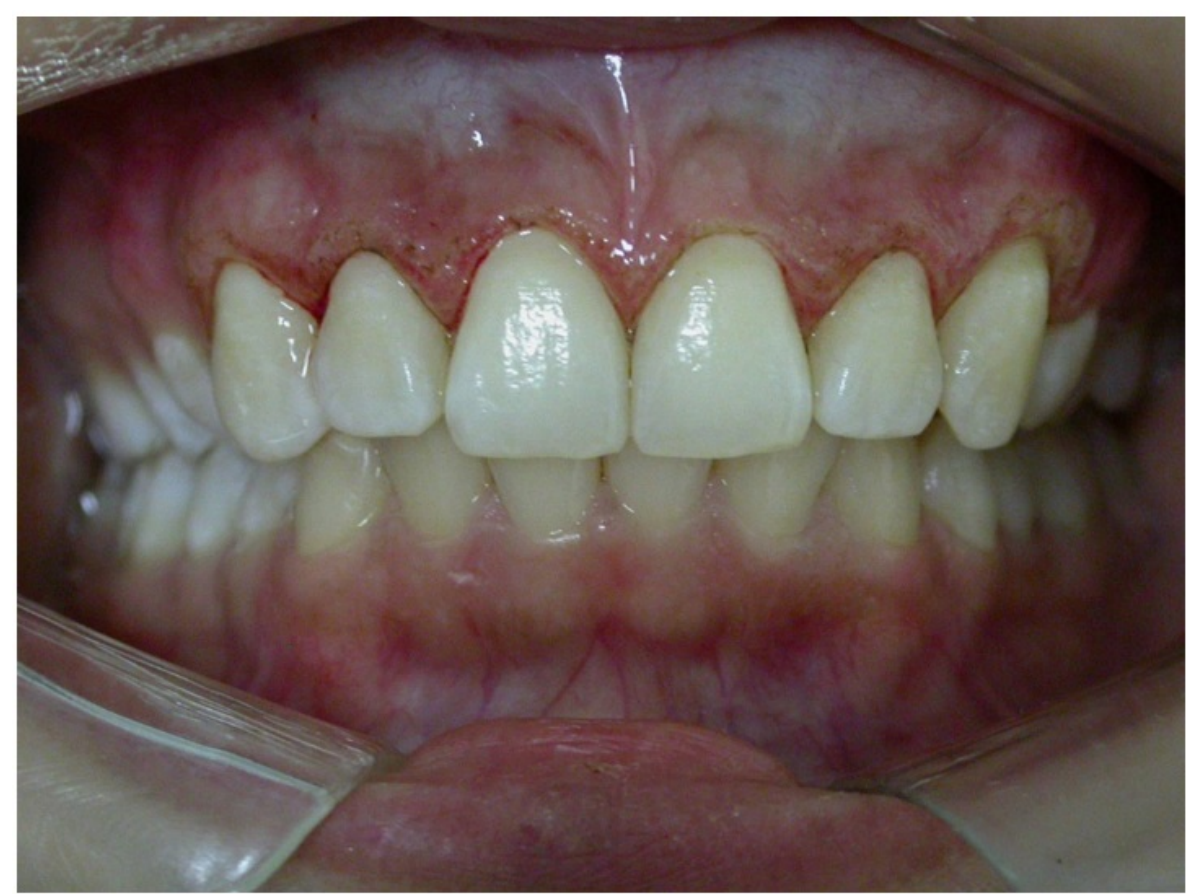

FIGURE 2

Immediate postoperative

Source: own elaboration.

After 30 days, satisfactory tissue repair was observed (Figure 3) and the patient reported no changes or complaints. However, the patient yet reported the complaint of gummy smile (Figure 4). The application of botulinum toxin was suggested, and the patient was counseled about the recurrence of the gummy smile after 6 months of application. 


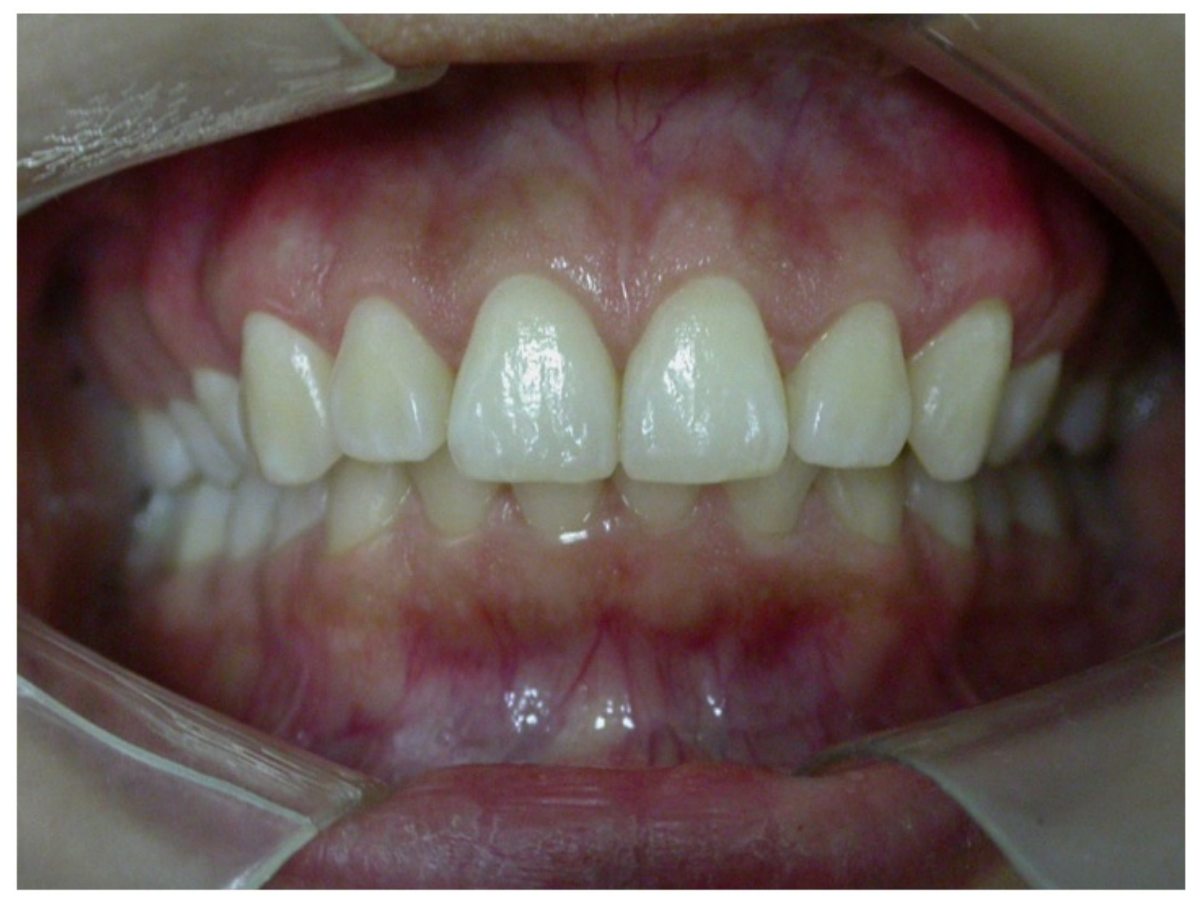

FIGURE 3

Post-surgical (30 days): satisfactory tissue reparation observed Source: own elaboration.

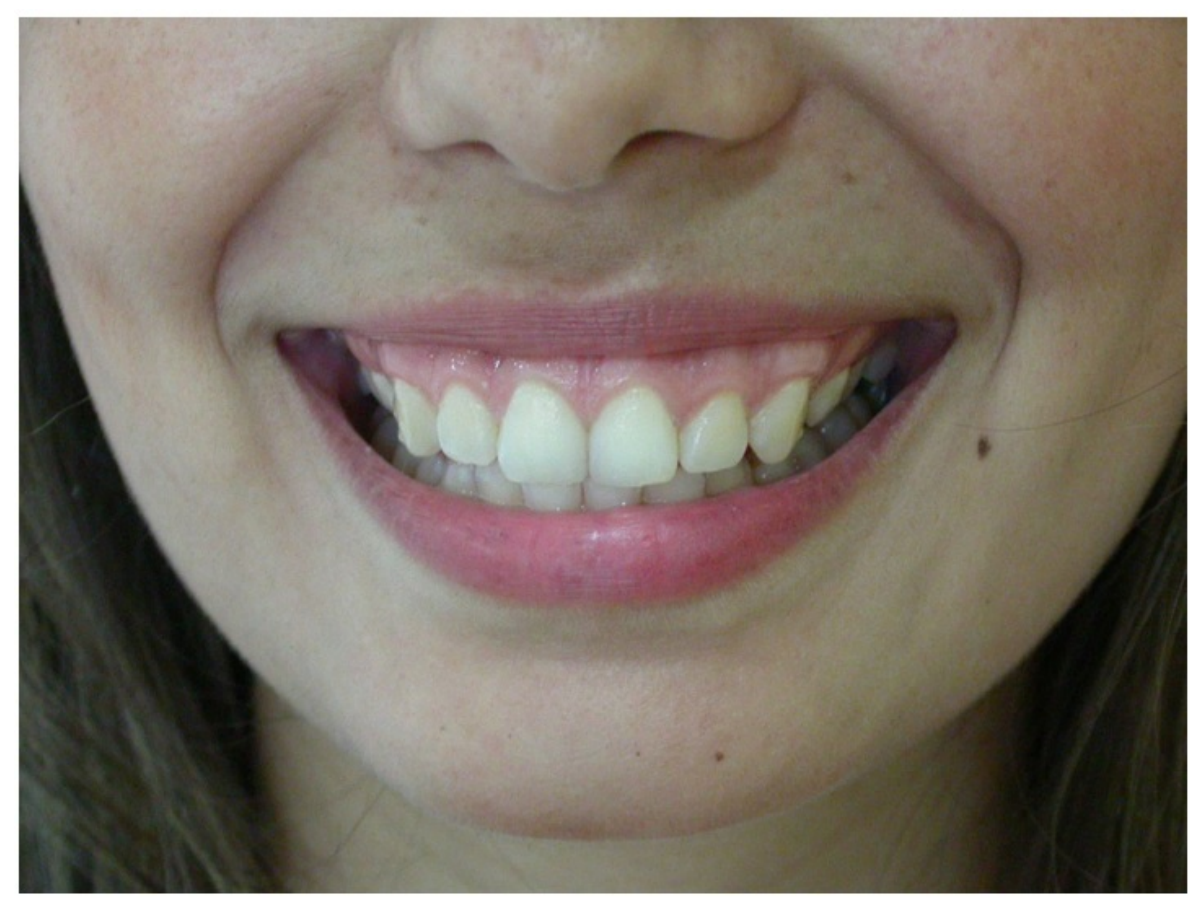

FIGURE 4

Persistence of gummy smile after gingivoplasty (30 days)

\author{
Source: own elaboration.
}

Prior to application of botulinum toxin, the surface of the skin was disinfected with ethanol, to avoid local infection and remove the oils from the skin. Posteriorly, local anesthetic (Emla ${ }^{\circledR}$ Astra, Sao Paulo, Brazil) was applied, with the purpose to promote comfort during the procedure. The botulinum toxin type A (Dysport ${ }^{\circ}$, Ipsen Biopharm Ltd, Wrexham, UK) was diluted in $1.7 \mathrm{ml}$ of saline, according to the 
manufacturer's instructions, and injected 2 units at the recommended site, laterally to each nostril. After application, the patient was advised do not lower her head and not engage in physical activity during the first 4 hours after the procedure.

After 10 days, the patient was evaluated presenting uniform dehiscence of the upper lip (Figure 5). Were no reported side effects or complaints. The patient was advised about the need for applications, on average, 6 months after the first, according to their needs.

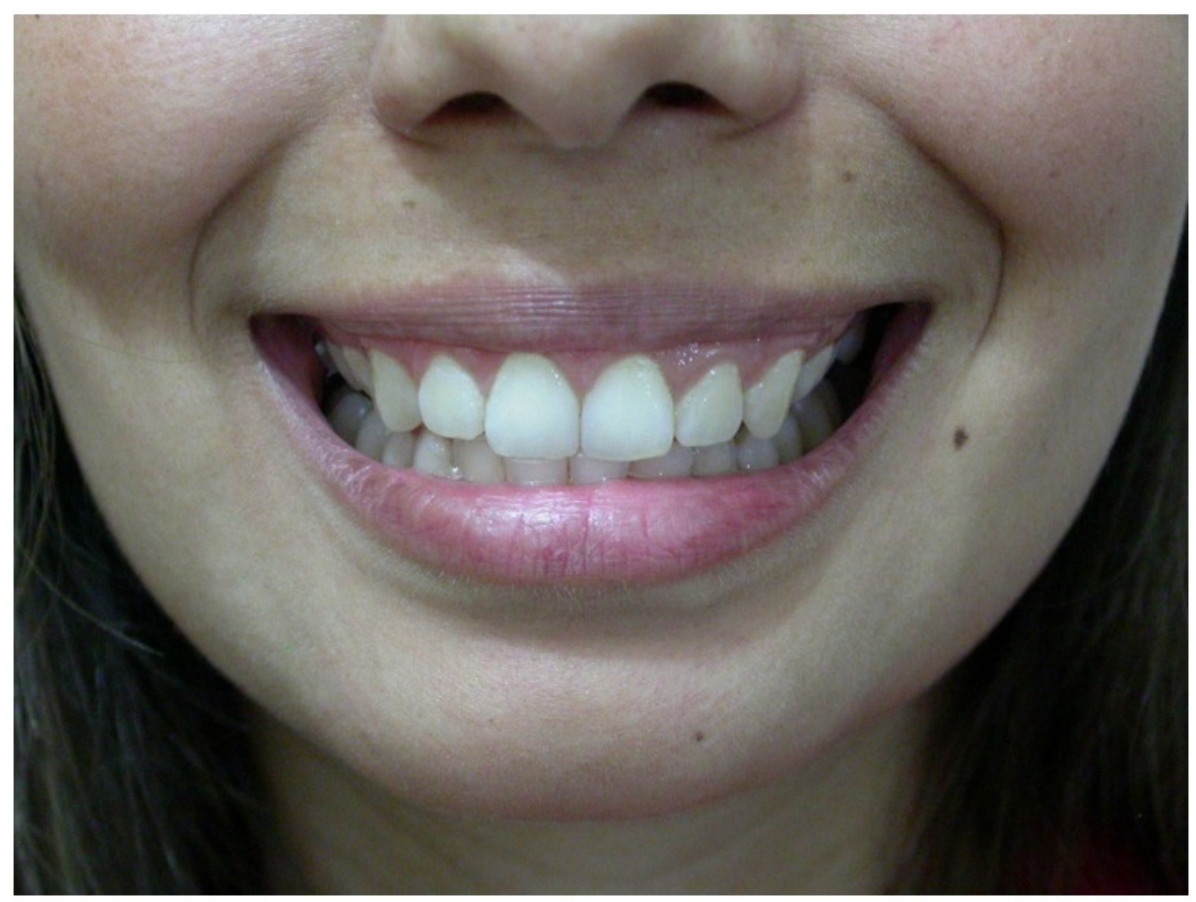

FIGURE 5

Aesthetic result after 10 days of botulinum toxin application

Source: own elaboration.

\section{Discussion}

Botulinum toxin has become an excellent auxiliary mean in the treatment of several dental disorders. Despite being known for cosmetic use in the reduction of hyperkinetic facial lines, it can also be used for therapeutic purposes in cases of bruxism, temporomandibular joint dysfunction, masseter hypertrophy and severe gingival exposure $(1,4,5,6,7,8,9,10,11)$.

The gummy smile is conceptualized by the exposure of more than $3 \mathrm{~mm}$ of gingival tissue during smiling $(1,5,7)$, and it is often found in women (10). The predominance of females can be explained by the fact that male patients present lower smile line $(4,5)$.

Several etiologies have been suggested to gummy smile, as vertical maxillary excess $(1,4,5,6,8,9)$, delayed passive eruption $(1,4,6,7,9)$, hyperfunction of the muscles involved in smiling $(1,6,7,9)$ and reduced length of the clinical crown of the teeth $(1,2,3,7)$, which can occur separately or together, and determine the type of treatment to be used.

In gummy smile caused by overactive muscle, botulinum toxin was indicated. It is the treatment of first choice for the ease and security of applications, quick effect, besides being a more conservative approach when compared to surgical procedures (myectomy or Le Fort I osteotomy) $(1,4,5,6,7,8,9,10,11$ ).

The activity of the smile is determined by several facial muscles, like the elevator of the upper lip and wing of the nose, the zygomatic major and minor, the angle of the mouth, orbicularis oris and risorius $(4,5,6,8,9,10)$. 
Among them, the first three ones play higher function and determine the amount of lip elevation and, therefore, should be the muscles affected by the injection of the toxin. The fibers of these muscles converge to the same area, and they form a triangle, what suggests that the point of adequate election comprehend the three muscles in a single injection. The toxin, when injected, can spread in an area of 10 to $30 \mathrm{~mm}$, what allows the effective extent $(4,5)$. The proposed site of injection was laterally to the wing of the nose $(4,8,9,10)$. After being injected into predetermined locations, the toxin decreases the contraction of the muscles responsible for the elevation of the upper lip, and this reduces gum exposure $(4,5,6,7,8,9,10,11)$.

Each muscle involved in the elevation of the upper lip has a function during the activity of smile. The points of the injections are determined by the contraction of specific muscle groups, that results in different areas of gingival display. Several classifications have been proposed to gummy smile: anterior, posterior, mixed and asymmetric, involving different muscle groups $(4,10)$.The anterior gummy smile should be treated with the conventional technique, with the applications laterally to the wing of the nose. In patients with posterior gummy smile, the application of the toxin must involve the zygomatic major and minor muscles, with the injection of the toxin in two different points: the point of greatest contraction of nasolabial during the activity of smile, and the second point $2 \mathrm{~cm}$ laterally to the first, at the level of the tragus line. In the case of patients who have mixed gummy smile, the application of the toxin should be performed on all the points mentioned above. However, the dose should be reduced to $50 \%$ in the lateral to the wing of the nose point (5. In cases of labial asymmetry, that occurs due to differences in muscle activity (4)the patients receive injections of different doses on either side of the face $(5,10)$.

Botulinum toxin type $\mathrm{A}$ is a hydrophilic powder, stored under vacuum, sterile and stable $(1,6,8$. The reconstitution occurs from the smooth injection of the diluent (sodium chloride $0.9 \%$ inside the bottle. The solution should be stored at 2 to $8^{\circ} \mathrm{C}$ and used within 4 to 8 hours, in order to ensure its effectiveness $(1,9)$.

At the beginning of the treatment, extraoral photographs, including the close-up of the smile, were performed. Some authors mentioned the importance of taking the picture of the smile before and after the application of the toxin $(1,6,10,11$. It has been suggested that the picture of the smile should be performed stimulating individually the muscles with electrical current, in order to ensure that muscle contraction be controlled, precise and repeatable, as the spontaneous smile is extremely difficult to be replicated. Patients understand that the treatment is carried out to produce a different smile, and, from this perspective, unconsciously, there is a tendency to smile differently in photographs after the treatment (11).

The clinical effects show up in 2-10 days after the injection, and the most visible effect occurs 14 days after the injection $(1,4,6)$.This first effect, scheduled to be progressive, is also reversible, lasting about 3 to 6 months $(1,5,6,9$. Patients should be advised of the need for applications, according to their tastes and needs, as was quoted in this report.

The injection of botulinum toxin, despite being a simple and safe procedure, may be associated with some adverse events such as: Pain at the injection site, bruising, infection, edema, dysphonia, dysphagia, ptosis or lengthening of the upper lip and asymmetry of the smile. The dentist should be attentive in relation to dosage, precision of technique and location of the puncture $(1,5,6,9,11$. In this report, claims or changes arising from the application were not reported.

Contraindications to the use of botulinum toxin are: pregnancy; lactation; hypersensitivity (allergy to botulinum toxin itself; lactose and albumin; muscle and neurodegenerative diseases (myasthenia gravis and Charcot's disease; and concurrent use of aminoglycoside antibiotic that enhances the action of the toxin $(1,9$.

In this report, the result was satisfactory to the harmony of the smile of the patient by association of treatments - gingivoplasty and application of botulinum toxin type A. The institution of isolated treatments could not culminate in the excellence of the earned results. Initially, the creation of the new dental zenith during the course of resective gingival surgery promoted the new dental architecture, favoring harmony gingival-dental-facial for the patient. Subsequently, the application of botulinum toxin type A softened the 
gummy smile, by the uniform dehiscence itself of the upper lip, still promoting smoothness to facial lines of the smile, as can be seen in the nasolabial folds, adjacent to the nostrils, comparing figures 4 and 5 .

\section{Conclusions}

The application of botulinum toxin is an alternative less invasive, faster, safer, more effective and it produces harmonics and pleasing results when applied in target muscles, respecting the appropriate dose and type of smile, and, therefore, it is a useful adjunct in the esthetic improvement of the smile and provides better results when combined with resective gingival surgery.

\section{Recommendations}

Based in this case report, future researches become important for the clinical evidence of this therapeutic association.

\section{References}

1. Pedron IG. Toxina botulínica: Aplicações em odontologia. Florianópolis, Brasil: Ponto; 2016.

2. Bashetty K, Nadig C, Kapoor S. Electrosurgery in esthetic and restorative dentistry: A literature review and case reports. J Conserv Dent. 2009 Oct; 12(4): 139-44. https://doi.org/10.4103/0972-0707.58332

3. Narayan S, Narayan TV, Jacob PC. Correction of gummy smile: a report of two cases. J Indian Soc Periodontol. 2011 Oct; 15(4): 421-4. https://doi.org/10.4103/0972-124X.92585

4. Hwang WS, Hur MS, Hu KS, Song WC, Koh KS, Baik HS, Kim ST, Kim HJ, Lee KJ. Surface anatomy of the lip elevator muscles for the treatment of gummy smile using botulinum toxin. Angle Orthod. 2009 Jan; 79(1): 70-7. https://doi.org/10.2319/091407-437.1

5. Mazzuco R, Hexsel D. Gummy smile and botulinum toxin: A new approach based on the gingival exposure area. J Am Acad Dermatol. 2010 Dec; 63(6): 1042-51. https://doi.org/10.1016/j.jaad.2010.02.053

6. Polo M. Botulinum toxin type A in the treatment of excessive gingival display. Am J Orthod Dentofacial Orthop. 2005 Feb; 127(2): 214-8. https://doi.org/10.1016/j.ajodo.2004.09.013

7. Mangano A, Mangano A. Current strategies in the treatment of gummy smile using botulinum toxin type A. Plast Reconstr Surg. 2012 Jun; 129(6): 1015e. https://doi.org/10.1097/PRS.0b013e31824f00a6

8. Indra AS, Biswas PP, Vineet VT, Yeshaswini T. Botox as an adjunct to orthognathic surgery for a case of severe vertical maxillary excess. J Maxillofac Oral Surg. 2011 Sep; 10(3):266-70. https://doi.org/10.1007/s12663-011-0178-0

9. Jaspers GWC, Pijpe J, Jansma J. The use of botulinum toxin type A in cosmetic facial procedures. Int J Oral Maxillofac Surg. 2011 Feb; 40(2): 127-33. https://doi.org/10.1016/j.ijom.2010.09.014

10. Sucupira E, Abramovitz A. A simplified method for smile enhancement: botulinum toxin injection for gummy smile. Plast Reconstr Surg. 2012 Sep; 130(3): 726-8. https://doi.org/10.1097/PRS.0b013e31825dc32f

11. Niamtu J 3rd. Botox injections for gummy smiles. Am J Orthod Dentofacial Orthop. 2008 Jun; 133(6): 782-3. h ttps://doi.org/10.1016/j.ajodo.2008.04.007

\section{Notes}

* Research article.

Licencia Creative Commons CC BY 4.0

How to cite this article: Pedron IG. Type A botulinum toxin as complement to gingivoplasty in the treatment of gummy smile. Case report. Univ Odontol. 2018 ene-jun; 37(78). https://doi.org/10.11144/ Javeriana.u o37-78.tabt 